International Journal of Molecular Medicine and Advance Sciences 6 (3): 43-48, 2010

ISSN: $1813-176 \mathrm{X}$

(C) Medwell Journals, 2010

\title{
Susceptibility Faecal Isolates of Commensal $E$. coli from Cattle to Fluoroquinolones and Cephalosporins
}

\author{
${ }^{1}$ A.O. Ajayi, ${ }^{2} \mathrm{O}$. Oluduro, ${ }^{3} \mathrm{O}$.A. Olowe and ${ }^{1,4} \mathrm{O}$. Famurewa \\ ${ }^{1}$ Department of Microbiology, University of Ado-Ekiti, P.M.B. 53536, Ado-Ekiti, Nigeria \\ ${ }^{2}$ Department of Microbiology, Faculty of Science, Obafemi Awolowo University, \\ Ile-Ife, Osun State, Nigeria \\ ${ }^{3}$ Department of Medical Microbiology and Parasitology, College of Health Sciences, \\ Ladoke Akintola University of Technology, Osogbo, Nigeria \\ ${ }^{4}$ College of Science, Engineering and Technology, Osun-State University, P.M.B. 4494, \\ Oke-Baale, Osogbo, Nigeria
}

\begin{abstract}
About 500 isolates of Escherichia coli were recovered from apparently healthy cattle and tested for their susceptibility to third generation cephalosporins and extended spectrum beta-lactamase producers were detected using the double dusk synergy test. Representative isolates were selected on the basis of their cephalosporin resistance patterns for plasmids analysis and mating experiment using $E$. coli 25922 as recipient. Resistance to cefoxitin was highest as $395(79.0 \%)$ showed resistance to the antibiotic while resistance to ceftriaxone was the lowest with $87(17.4 \%)$ isolates. Seventy two isolates were confirmed to be extended spectrum beta-lactamase producers. Two of 13 representative isolates selected among the extended spectrum beta lactamase producers carried single plasmids while the remaining 11 isolates contain multiple plasmids ranging from 1.2-22.2 $\mathrm{kb}$. The cephalosporin-resistant isolates also carried plasmids with sizes ranging from $4.32-32 \mathrm{~kb}$. Twelve isolates among the extended spectrum beta-lactamase producers that carried plasmids successfully transferred the plasmids to the recipient while all the cephalosporin-resistant isolates successful transferred plasmids to the recipient strain. The use of third-generation cephalosporins in animal medicine should be regulated.
\end{abstract}

Key words: Cephalosporins, animal medicine, regulated plasmids, spectrum, beta-lactamase, Nigeria

\section{INTRODUCTION}

The cephalosporins are powerful broad-spectrum antibiotics widely accepted as for use in clinical and animal medicine. They have been successfully utilised for effective treatment and control of human infections and more recently are increasingly being deployed for various uses in animal care and husbandry. They demonstrate vast bactericidal action against gram-positive and negative bacteria and their uses have been extended for use in ruminants, cattle and poultry following the success achieved for their use in human medicine. Furthermore, recent reports have indicated that larger quantities of cephalosporins are being deployed for use in animals and this have fuelled concerns regarding the potential detrimental effect of the use of cephalosporins in humans and livestock and in particular, the emergence of cephalosporin resistant bacteria which have been confirmed to be due to their increasing use in animals (Singer et al., 2008). Another contributory factor for the increasing incidence of resistance among enteric bacteria to cephalosporins is the use in livestock of third generation cephalosporins which were originally licensed for use for treatment and prevention of infections in humans due to their broad spectrum and bactericidal activity (Tenover, 2006).

For instance, some third-generation cephalosporin with many applications in human medicine including the treatment of severe salmonellosis, diarrhoea and other mild or intestinal diseases caused by enteric bacteria in humans (Whichard et al., 2005).

In addition, their uses in treatment of animal infections, particularly pneumoniae, mastitis, postpartum metritis and necrotising pododermatitis have been documented (Daniels et al., 2009) while they found greater roles in prevention of infections in livestock, enhancement of weight gain to increase beef production and their incorporation into animal food and drinks. The various mechanisms of resistance against cephalosporins have been reported. The most common

Corresponding Author: O. Famurewa, Department of Microbiology, University of Ado-Ekiti, P.M.B. 53536, Ado-Ekiti, Nigeria 
mechanism of resistance against third-generation cephalosporins is through the production of extended spectrum beta-lactamases called cephalosporinases that act against the core beta-lactam ring of the antibiotics (Whichard et al., 2005). In gram negative pathogens, cephaloporinases confer resistance against cefotaxime, azreonam, cefoxitin and ceftriaxone and the cephalosporin-resistant bacteria in livestock have become prevalent worldwide (Livermore et al., 2007; Madec et al., 2008). Extended spectrum beta-lactamases are always coded by plasmids when they occur in gram negative bacteria and various plasmid-mediated cephalosporinases that occur in enteric bacteria have been described (Zioga et al., 2009).

\section{MATERIALS AND METHODS}

Bacterial isolation: About 500 isolates of $E$. coli were recovered from faeces of apparently health cattle using sterile faecal swab sticks. The faecal swabs were inoculated directly onto eosine methylene blue agar plates and isolates with morphological appearance of characteristic green metallic sheen were presumptively identified as E. coli. All isolates were further confirmed using standard biochemical tests.

Antibiotic susceptibility tests: Antibiotic susceptibility tests were carried out to determine their susceptibility to third-generation cephalosporins and also to determine whether the isolates are extended-spectrum $\beta$-lactamase producers using the double disk synergy test. The cephalosporins used were: aztreonam $(25 \mu \mathrm{g})$, cefoxitin $(25 \mu \mathrm{g})$, ceftriaxone $(25 \mu \mathrm{g})$ and ceftazidime $(25 \mu \mathrm{g})$ (Oxoid, UK). In the disk synergy test, disks containing combination of amoxicillin-claviculanic acid was placed at the center of Mueller-Hinton agar plates and the respective cephalosporin disks were placed between 20-30 $\mathrm{mm}$ equidistant from the amoxicillin-claviculanic acid. Plates were incubated at $35^{\circ} \mathrm{C}$ for $24 \mathrm{~h}$ and checked for enhanced zones of inhibition. Those isolates that showed resistance to individual cephalosporins but are non-extended spectrum beta-lactamase producers were also examined and those isolates which showed multiple resistance to the cephalosporins were noted.

Plasmid analysis: Plasmid analysis was carried out on two separate sets of representative isolates: fiftreen extended spectrum beta-lactamase producers and non-extended spectrum beta-lactamase cephalosporinresistant isolates of $E$. coli. The modified alkaline method for plasmid extraction described by Birnboim and Doly (1979) was used for plasmid extraction. Plasmids bands were seperated and using $1 \%$ agarose gel electrophporesis and visualised using the ultra violet transillumination.

Conjugation studies: Mating experiments were carried out on all isolates that were confirmed to carry plasmids. The plasmid-free recipient strain $E$. coli 25922 was obtained at the department of Microbiology, Obafemi Awolowo University, Ile-Ife. The donors and the recipient strain were mated in separate tubes in $1: 9 \mathrm{vol} / \mathrm{vol}$. transconjugants were selected on Mueller-Hinton agar plates containing ampicillin $\left(50 \mu \mathrm{g} \mathrm{mL}^{-1}\right)$ and tetracycline $\left(50 \mu \mathrm{g} \mathrm{mL}^{-1}\right.$ ). The frequency of conjugation was estimated on all transconjugant plates.

\section{RESULTS AND DISCUSSION}

About 72 isolates of $E$. coli showed enhanced zone of diffusion indicating that they are presumptively extended spectrum beta-lactamase producers. Resistance to cefoxitin was highest while resistance to ceftriaxone was the lowest (Table 1). About 158 isolates showed multiple cephalosporin resistance and eleven different cephalosporin resistance patterns were observed among those isolates that showed multiple cephalosporinresistance (Table 2). Among the representative ESBL producing isolates, five different plasmid profiles were observed comprising between two and four plasmid bands (Fig. 1) while the representatives of the cephalosporin resistant isolates yielded four plasmid

Table 1: Antibiotic resistance of isolates against single cephalosporins

\begin{tabular}{lc}
\hline Antibiotics & Number $(\%) \mathrm{n}=500$ \\
\hline Cefoxitin & $395(79.0)$ \\
Amixicillin-claviculanic acid & $325(65.0)^{*}$ \\
Ceftazidime & $242(48.4)$ \\
Azreonam & $202(40.4)$ \\
Ceftriaxone & $87(17.4)$ \\
\hline
\end{tabular}

Table 2: Multiple cephalosporin resistance phenotypes

\begin{tabular}{|c|c|c|c|c|c|c|c|}
\hline \multirow{2}{*}{$\frac{\mathrm{S} / \mathrm{N}}{1}$} & \multirow{2}{*}{$\begin{array}{c}\begin{array}{c}\text { No. of } \\
\text { cephalosp orins }\end{array} \\
2\end{array}$} & \multicolumn{5}{|c|}{--------Resistance phenotypes----------- } & \multirow{2}{*}{$\begin{array}{c}\begin{array}{c}\text { No. of } \\
\text { isolates }\end{array} \\
60\end{array}$} \\
\hline & & Amc & Fox & & & & \\
\hline 2 & & Fox & $\mathrm{Caz}$ & & & & 06 \\
\hline 3 & & Atm & Fox & & & & 11 \\
\hline Total & & & & & & & 77 \\
\hline 4 & 3 & Amc & Fox & $\mathrm{Caz}$ & & & 06 \\
\hline 5 & & Amc & Atm & Fox & & & 32 \\
\hline 6 & & Atm & Fox & $\mathrm{Caz}$ & & & 02 \\
\hline Total & & & & & & & 40 \\
\hline 7 & 4 & Amc & Atm & Fox & $\mathrm{Caz}$ & & 13 \\
\hline 8 & & Atm & Fox & $\mathrm{Caz}$ & Cro & & 06 \\
\hline 9 & & Amc & Fox & $\mathrm{Caz}$ & Cro & & 02 \\
\hline 10 & & Amc & Atm & Fox & Cro & & 05 \\
\hline Total & & & & & & & 26 \\
\hline 11 & 5 & Amc & Atm & $\mathrm{Caz}$ & Cro & Fox & 12 \\
\hline$\underline{\text { Total }}$ & & & & & & & 12 \\
\hline
\end{tabular}

Amc: Amoxicillin-claviculanic acid, Atm: Azreonam, Caz: Ceftazidime, Cro: Ceftriaxone, Fox: Cefoxitin 


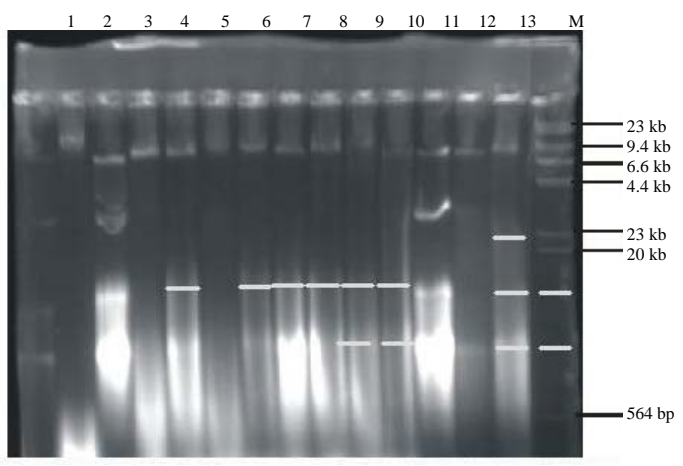

Fig. 1: Plasmid profile of representative isolates of extended spectrum $\beta$-lactamose producers among E. coli; Lane 1: E662, $22 \mathrm{~kb}$; Lane 2: E660, 8.9, 3.7, 1.6 and $12 \mathrm{~kb}$; Lane 3: E647, 933 and $569 \mathrm{~kb}$; Lane 4: E595, 933, 16 and $12 \mathrm{~kb}$; Lane 5: E563, $933 \mathrm{~kb}$; Lane 6: E513, 933, 1.6 and 12kb; Lane 7: E506, 933, 1.6 and $12 \mathrm{~kb}$; Lane 8: E496, 933, 1.6 and $12 \mathrm{~kb}$; Lane 9: E494, 9.42, 16 and $12 \mathrm{~kb}$; Lane 10: E480, 9.44 and $12 \mathrm{~kb}$; Lane 11: E469, 933, 3.7, 16 and1 2 $\mathrm{kb}$; Lane 12: E434, 933, 3.7, 1.6 and12 kb; Lane 13: E429, 933, 3.7, 1.6 and $12 \mathrm{~kb}$; Lane M: Marker, Lambda Hind III dige 1

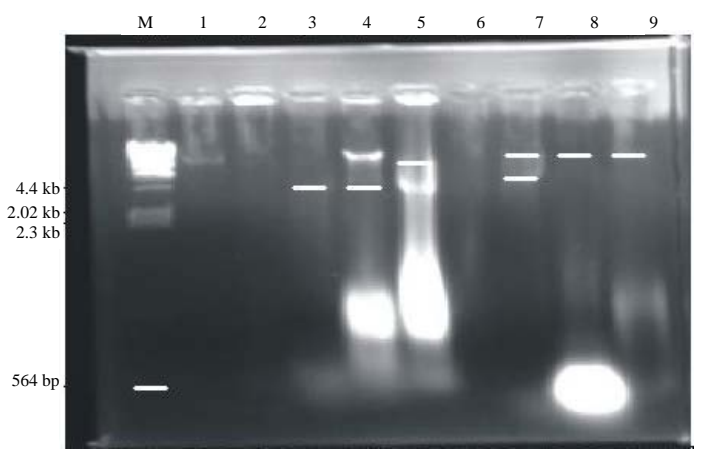

Fig. 2: Plasmid profile of representative isolates of cephalosporin-resistant E. coli $\left(\mathrm{GEL}_{1}\right)$; Lane 1: E649, $686 \mathrm{~kb}$; Lane 3: E643, $4.3 \mathrm{~kb}$; Lane 4: E630, 192 and $433 \mathrm{~kb}$; Lane 5: E608, $559 \mathrm{~kb}$; $432 \mathrm{~kb}$; Lane 7: E563, 792 and 530 kb; Lane8: E543, 792kb, 5.30 $\mathrm{kb}$; Lane 9: E410, $7.92 \mathrm{~kb}$

profiles with on or two plasmids (Fig. 2 and 3). In the mating experiment, the frequency of conjugation among the ESBL producing isolates ranged between zero and $3.1 \times 10^{-3}$ (Table 3) while it ranged between $1.4 \times 10^{-5}$ and $1.8 \times 10^{-3}$ among the cephalosporin-resistant isolates (Table 4 and 5).

Five hundred isolates of commensal Escherichia coli were recovered from apparently healthy cattle and they were subjected to antibiotic susceptibility tests to determine resistance to third-generation cephalosporins

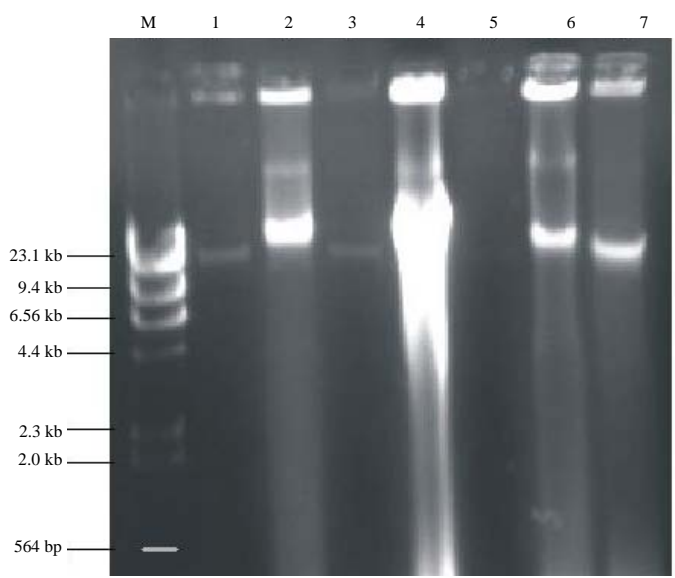

Fig. 3: Plasmid profile of representative isolates of cephalosporin-resistant E. coli $\left(\mathrm{GEL}_{2}\right)$; Lane $\mathrm{M}$ : Marker, Lambda hind III dige 1; Lane 1: E397, 23.3 $\mathrm{kb}$; Lane 2: E322, 34.0 and $26.7 \mathrm{~kb}$; Lane 3: E1 55, $233 \mathrm{~kb}$; Lane 4: E157, 34.0 kb; Lane 6: E567, 34.0 and $23.3 \mathrm{~kb}$; Lane 7: E255, $23.3 \mathrm{~kb}$

Table 3: Result for transconjugants selected among extended spectrum $\beta$ lactamase producers

\begin{tabular}{|c|c|c|c|}
\hline Lanes & Isolate code & $\begin{array}{l}\text { Frequency of conjugation } \\
\text { (Transconjugants } \\
\text { /donor cells) }\end{array}$ & $\mathrm{MIC}\left(\mathrm{mg} \mathrm{L}^{-1}\right)$ \\
\hline$\overline{1}$ & E662 & $1.2 \times 10^{-4}$ & 64 \\
\hline 2 & E660 & $2.7 \times 10^{-4}$ & 64 \\
\hline 3 & $\mathrm{E} 647$ & $1.7 \times 10^{-5}$ & 32 \\
\hline 4 & E595 & $2.6 \times 10^{-5}$ & 64 \\
\hline 5 & E536 & 0.0 & 64 \\
\hline 6 & E513 & $2.2 \times 10^{-3}$ & 64 \\
\hline 7. & E506 & $2.4 \times 10^{-5}$ & $>64$ \\
\hline 8 & E496 & $2.0 \times 10^{-4}$ & 32 \\
\hline 9. & E494 & $2.7 \times 10^{-5}$ & 32 \\
\hline 10 & $\mathrm{E} 480$ & $3.5 \times 10^{-5}$ & 16 \\
\hline 11. & E469 & $1.8 \times 10^{-5}$ & $>64$ \\
\hline 12 & $\mathrm{E} 434$ & $2.9 \times 10^{-5}$ & 32 \\
\hline 13 & E429 & $3.1 \times 10^{-3}$ & 64 \\
\hline
\end{tabular}

and also to determine whether they are extended spectrum beta-lactamase producers using the double disk synergy test. First, it was observed in this study that the prevalence of cephalosporin resistance among the five hundred representative isolates was very high with resistance against cefoxitin being highest as $395(79.0 \%)$ isolates showed resistance to the antibiotic while resistance to ceftriaxone was the least.

Third-generation cephalosporins were used because of their heavy use in humans and animals, probably due to their improved activity, enhanced spectrum of activity and improved pharmacokinetic that ensure penetration of body tissues within the shortest time. These improved qualities make them suitable for use in cattle and other animals. It was also observed that some of the isolates are 
Int. J. Mol. Med. Adv. Sci., 6 (3): 43-48, 2010

Table 4: Result for transconjugants selected among cephalosporin-resistant

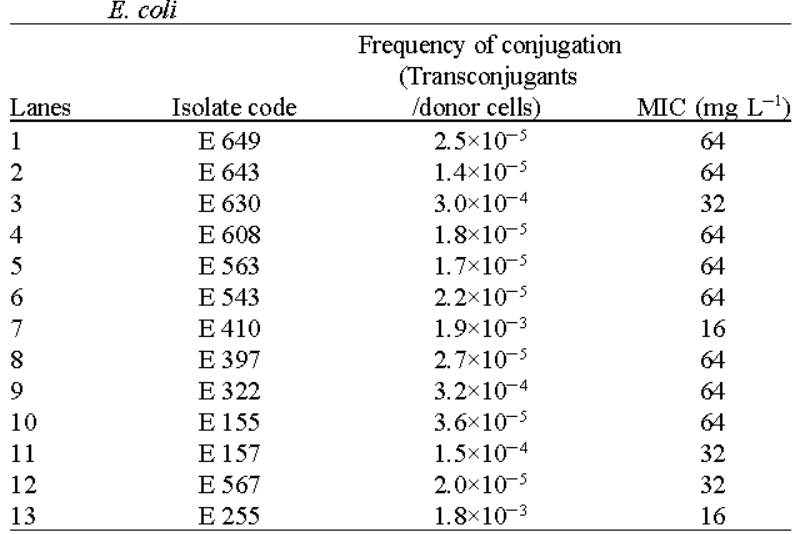

Table 5: Plasmid profile of cephalosporin-resistant isolates (GEL 2)

\begin{tabular}{llcl} 
Lanes & $\begin{array}{c}\text { Strain } \\
\text { code }\end{array}$ & $\begin{array}{c}\text { Plasmid } \\
\text { bands (Approx. kb) }\end{array}$ & $\begin{array}{l}\text { Cephalosporin } \\
\text { resistance phenotypes }\end{array}$ \\
\hline $\mathrm{M}$ & - & - & - \\
1 & E 397 & 23.3 & $\mathrm{Atm} / \mathrm{Fox} / \mathrm{Caz} / \mathrm{Cro}$ \\
2 & E 322 & 34.0 & $\mathrm{Amc} / \mathrm{Atm} / \mathrm{Fox} / \mathrm{Caz}$ \\
& & 26.7 & \\
3 & E 155 & 23.3 & $\mathrm{Amc} / \mathrm{Fox} / \mathrm{Caz} / \mathrm{Cro}$ \\
4 & E 157 & 34.0 & $\mathrm{Amc} / \mathrm{Fox} / \mathrm{Caz} / \mathrm{Cro}$ \\
5 & E 71 & - & $\mathrm{Amc} / \mathrm{Atm} / \mathrm{Fox} / \mathrm{Caz}$ \\
6 & E 567 & 34.0 & $\mathrm{Amc} / \mathrm{Atm} / \mathrm{Fox} / \mathrm{Cro}$ \\
& & 25.5 & \\
7 & E 255 & 23.3 & $\mathrm{Amc} / \mathrm{Atm} / \mathrm{Fox} / \mathrm{Caz}$
\end{tabular}

Amp: Ampicillin, Col: Colistin, Cot: Cotrimoxazole, Gen: Gentamicin, Nal: Nalidixic-acid, Nit: Nitrofurantoin, Tet: Tetracycline, Strep: Streptomycin, Amc: Amoxicillin-claviculanic acid, Atm: Azreonam, Fox: Cefoxitin, Cro: Ceftriaxone, Caz: Ceftazidime

extended spectrum $\beta$-lactamase producers and this could be responsible for the high incidence of cephalosporinresistance among the isolates. Production of $\beta$-lactamases is the major mechanism through which bacteria develop resistance to cephalosporins. By definition, extended spectrum $\beta$-lactamases are enzymes elaborated by organisms and the inactivate penicillins and cephalosporins through hydrolysis of the $\beta$-lactam core ring in the antibiotics (Daniels et al., 2009).

In this study, we detected and characterised plasmids that ranged between $22.2-1.2 \mathrm{~kb}$ among the $E$. coli isolates which produced extended spectrum beta-lactamases. On the contrary, those plasmids with narrower range of sizes between 23.3 and $4.35 \mathrm{~kb}$ were conspicuous among the cephalosporin-resistant isolates. Profiles of multiple plasmids of between two to four plasmids were more predominant among the extended spectrum betalactamase producing $E$. coli strains under study while the multiple profiles of plasmids were comparatively less pronounced among the cephalosporin-resistant strains with a maximum of two plasmid bands (Table 6 and 7).

Previous studies have reported and characterised plasmids carried by many enteric bacteria which were confirmed resistant not only to common antibiotics but
Table 6: Plasmid profile of ESBL producing isolates

\begin{tabular}{llll}
\hline Lanes & $\begin{array}{c}\text { Isolate } \\
\text { code }\end{array}$ & $\begin{array}{c}\text { Plasmid } \\
\text { bands (Approx.) }(\mathrm{kb})\end{array}$ & $\begin{array}{l}\text { Cephalosporin } \\
\text { resistance phenotypes }\end{array}$ \\
\hline $\mathrm{M}$ & - & - & - \\
1 & E 662 & 22.2 & - \\
2 & E 660 & $8.9,3.7,1.6,1.2$ & Cro/Caz \\
3 & E 647 & $9.33,569 \mathrm{bp}$ & Fox \\
4 & E 595 & $9.33,1.6,1.2$ & Fox \\
5 & E 536 & 9.33 & Amc \\
6 & E 513 & $9.33,1.6,1.2$ & Amc/Fox/Caz \\
7 & E 506 & $9.33,1.6,1.2$ & Fox/Caz \\
8 & E 496 & $9.33,1.6,1.2$ & Fox \\
9 & E 494 & $9.42,1.6,1.2$ & Fox \\
10 & E 480 & $9.44,1.2$ & Fox \\
11 & E 469 & $9.33,3.7,1.6,1.2$ & Fox \\
12 & E 434 & $9.33,3.7,1.6,1.2$ & Fox \\
13 & E 429 & $9.33,3.7,1.6,1.2$ & Amc/Fox \\
\hline A
\end{tabular}

Amp: Ampicillin, Col: Colistin, Cot: Cotrimoxazole, Gen: Gentamicin, Nal: Nalidixic-acid, Nit: Nitrofurantoin, Tet: Tetracycline, Strep: Streptomycin, Amc: Amoxicillin-claviculanic acid, Atm: Azreonam, Caz: Ceftazidime, Cro: Ceftriaxone, Fox: Cefoxitin

\begin{tabular}{|c|c|c|c|}
\hline Lanes & $\begin{array}{l}\text { Isolate } \\
\text { code }\end{array}$ & $\begin{array}{c}\text { Plasmid } \\
\text { bands (Approx.) }(\mathrm{kb})\end{array}$ & $\begin{array}{l}\text { Cephalosp orin } \\
\text { resistance phenotypes }\end{array}$ \\
\hline $\mathrm{M}$ & & & - \\
\hline 1 & E 649 & 7.9 & $\mathrm{Amc} / \mathrm{Cro} / \mathrm{Caz}$ \\
\hline $2^{*}$ & E 645 & - & $\mathrm{Amc} / \mathrm{Atm} / \mathrm{Fox} / \mathrm{Caz} / \mathrm{Cro}$ \\
\hline 3 & E 643 & 4.32 & $\mathrm{Amc} / \mathrm{Atm} / \mathrm{Fox} / \mathrm{Caz}$ \\
\hline 4 & E 630 & $7.92,4.35$ & $\mathrm{Amc} / \mathrm{Atm} / \mathrm{Fox} / \mathrm{Caz} / \mathrm{Crc}$ \\
\hline 5 & E 608 & $5.59,4.32$ & $\mathrm{Amc} / \mathrm{Atm} / \mathrm{Fox} / \mathrm{Caz} / \mathrm{Crc}$ \\
\hline 6 & E 593 & - & $\mathrm{Amc} / \mathrm{Atm} / \mathrm{Fox} / \mathrm{Caz} / \mathrm{Cro}$ \\
\hline 7 & E 563 & $7.92,5.30$ & $\mathrm{Amc} / \mathrm{Fox} / \mathrm{Caz} / \mathrm{Cro}$ \\
\hline 8 & E 543 & 7.92 & $\mathrm{Amc} / \mathrm{Atm} / \mathrm{Fox} / \mathrm{Caz} / \mathrm{Crc}$ \\
\hline 9 & E 410 & 7.92 & Amc/Atm/Fox/Caz \\
\hline
\end{tabular}

Amp: Ampicillin, Col: Colistin, Cot: Cotrimoxazole, Gen: Gentamicin, Nal: Nalidixic-acid, Nit: Nitrofurantoin, Tet: Tetracycline, Strep: Streptomycin, Amc: Amoxicillin-claviculanic acid, Atm: Azreonam, Fox: Cefoxitin, Cro: Ceftriaxone, ceftazidime

more specifically to beta lactam antibiotics. The major findings on the presence of single or multiple plasmids among extended spectrum $\beta$-lactamse producing $E$. coli and those isolates that showed resistance to cephalosporins correlate with the findings from such reports (Winokur et al., 2001; Daniels et al., 2007). More specifically, Winokur et al. (2001) described plasmids recovered from food animals which confer resistance against ampicillin and some cephalosporins. The presence of multiple resistance plasmids among enteric bacteria from human and animal sources as observed in this present study has been established to have similar clonalities when they are found in the similar environments (Oppegaard et al., 2001). Other enteric bacteria, particularly Salmonella isolated from cattle have also been confirmed to carry cephalosporin-resistance plasmids (Aarestrup et al., 2004). Daniels et al. (2007), described the clonality of plasmids carrying beta lactamase genes among Salmonella enterica and E. coli recovered from cattle. This study has shown that generally, plasmids were transferred at relatively high 
frequency as revealed by the calculated frequencies of transfer of plasmids detected in some of the representative isolates. All the representative ESBL producing isolates in this study carried plasmids and it was observed that these isolates transferred plasmids at the highest frequency of conjugation compared with the other categories of isolates under study that also carried plasmids. The results obtained from the mating experiment carried out in this study agree with other studies that equally determined the rate of transfer of plasmids among bacteria. In a study to determine the conjugative transfer of ESBL genes among Salmonella recovered from poultry and poultry meat, plasmid borne ESBL genes were confirmed to be located on plasmids in Salmonella were successfully conjugated with plasmid free recipient that subsequently conferred resistance to the bacteria (Hasman et al., 2005). Furthermore, conjugative transfer of resistant plasmids does not occur only in $E$. coli, other reports have also shown that such plasmids can also be transferred among other bacteria in the Enterobacteriacaea, particularly Salmonella, Eterobacter and Shigella (Dionisi et al., 2009).

It has been noted that enteric bacteria transfer antibiotic resistance plasmids through a fundamentally similar process of conjugation, irrespective of the environments in which such bacteria are found (Garza-Ramos et al., 2007). All the extended spectrum $\beta$ lactamase producing and cephalosporin-resistant isolates that carried plasmids in this present research were isolated from cattle and transconjugants were also derived from all isolates at different frequencies of conjugation.

\section{CONCLUSION}

In accordance with the results obtained in this present study, several studies have also indicated the derivation of transconjugants as a result of conjugative transfer of plasmids that carry genes that code for extended spectrum $\beta$-lactamases (Smet et al., 2009). The high prevalence of resistance to cephalosporins observed in this study could be due to overdependence of the antibiotics for use in animal management in the study location (Singer et al., 2008; Wagner et al., 2008). The implications of the transfer of antibiotic resistance plasmids to other related bacteria are of immense magnitude to environmental and public health. The high prevalence of cephalosporin-resistance among the faecal isolates of $E$. coli from cattle as observed in this present study may be attributed to the extensive transfer of plasmids that code for antibioticresistance to other related bacteria within the same environment as confirmed by the mating experiments. The high frequency of transfer of antibiotic resistance plasmids among enteric bacteria connotes that such bacteria could easily be disseminated into the immediate environment through faecal shedding and such bacteria could contaminate the food chain which is a crucial route through which such bacteria could infect humans through intake of food and drinking water that are contaminated with a sizeable population of antibiotic-resistant enteric bacteri (Witte, 1998). Stringent regulatory regimes for the use of cephalosporins in animals must be enforced to curb the high incidence of cephalosporin resistance in animals, particularly cattle.

\section{REFERENCES}

Aarestrup, F.M., H. Hasman, I. Olsen and G. Sørensen, 2004. International spread of blaCMY-2-mediated cephalosporin resistance in a multi-resistant Salmonella enterica serovar heidelberg isolate stemming from the importation of a boar by denmark from Canada. Antimicrob. Agents Chemother., 48: 1916-1917.

Birnboim, H.C. and J. Doly, 1979. A rapid alkaline extraction procedure for screening recombinant plasmid DNA. Nucleic Acids Res., 7: 1513-1523.

Daniels, J.B., D.R. Call and T.E. Besser, 2007. Molecular epidemiology of blaCMY-2 plasmids carried by Salmonella enterica and Escherichia coli isolates from cattle in the pacific northwest. Applied Environ. Microbiol., 73: 8005-8011.

Daniels, J.B., D.R. Call, D. Hancock, W.M. Sischo, K. Baker and T.E. Besser, 2009. Role of ceftiofur in selection and dissemination of blaCMY-2-mediated cephalosporin resistance in salmonella enterica and commensal Escherichia coli isolates from cattle. Applied Environ. Microbiol., 75: 3648-3655.

Dionisi, A.M., C. Laucarlli, S. Owczarek, I. Luzzi and L. Villa, 2009. Characterization of plasmids-borne quinolone resistance gene qnrB19 in Salmonella enterica serovar typhimurium. Antimicrob. Agents Chemother., 53: 4019-4021.

Garza-Ramos, U., E. Martinez-Romero and J. SilvaSanchez, 2007. SHV-type Extended-spectrum $\beta$ lactamase (ESBL) are encoded in related plasmids from enterobacteria clinical isolates from Mexico. Salud Publica Mexico, 49: 415-421.

Hasman, H., D. Mevius, K. Veldman, I. Olesen and M.F. Aarestru, 2005. Beta-lactamses among Extended Spectrum Beta Lactamase (ESBL)-resistant Salmonella from poultry, poultry products and human patients in the Netherlands. J. Antimicrob. Chemther, 56: 115-121. 
Livermore, D.M., R. Canton, M. Gniadkowski, P. Nordmann and G.M. Rossolini et al., 2007. CTX-M: Changing the face of extended spectrum $\beta$ lactamases in Europe. J. Antimicrob. Chemother., 59: 165-174.

Madec, J., S. Martin, P. Libereton and T. Rambaud, 2008. Prevalence of fecal carriage of acquired expanded-spectrum cephalosporin resistance in Enterobacteriaceae strains from cattle in France. J. Clin. Microbiol., 46: 1566-1567.

Oppegaard, H., T.M. Steinum and Y. Wasteson, 2001. Horizontal transfer of a multi-drug resistance plasmid between coliform bacteria of human and bovine origin in a farm environment. Applied Environ. Microbiol., 67: 3732-3734.

Singer, R.S., S.K. Patterson and R.L. Wallace, 2008. Effects of therapeutic ceftiofur administration to dairy cattle on Escherichia coli dynamics in the intestinal tract. Applied Environ. Microbiol., 74: 6956-6962.

Smet, A., A. Martel, D. Persoons, J. Dewulf and M. Heyndrickx et al., 2009. Comparative analysis of extended-spectrum- $\beta$-lactamase-carrying plasmids from different members of Enterobacteriaceae isolated from poultry, pigs and humans: Evidence for a shared $\beta$-lactam resistance gene pool. J. Antimicrob. Chemother., 63: 1286-1288.
Tenover, F.C., 2006. Mechanisms of antimicrobial resistance in bacteria. Am. J. Med., 119: 3-10.

Wagner, B.A., B.E. Straw, P.J. Fedorka-Cray and D.A. Dargatz, 2008. Effect of antimicrobial dosage regimen on salmonella and Escherichia coli isolates from feeder Swine. Applied Environ. Microbiol., 74: 1731-1739.

Whichard, J.M., K. Joyce, P.D. Fey, J.M. Nelson, F.J. Angulo and T.J. Barrett, 2005. Beta-lactam resistance and Enterobacteriaceae, United States. Emerg. Infect. Dis., 11: 1464-1466.

Winokur, P.L., D.L. Vonstein, L.J. Hoffman, E.K. Uhlenhopp and G.V. Doern, 2001. Evidence for transfer of CMY-2 AmpC $\beta$-lactamase plasmids between Escherichia coli and Salmonella isolates from food animals and humans. Antimicrob. Agents Chemother., 45: 2716-2722.

Witte, W., 1998. Medical consequence of antibiotic use in agriculture. Science, 279: 996-997.

Zioga, A., J.M. Whichard, S.D. Kotsakis, L.S. Tzouvelekis, E. Tzelepi and V. Miriagou, 2009. CMY-31 and CMY-36 cephalosporinases encoded by ColE1-like plasmids. Antimicrob. Agents Chemother., 353: 1256-1259. 